\title{
Quality Control Deficiency
}

National Cancer Institute

\section{Source}

National Cancer Institute. Quality Control Deficiency. NCI Thesaurus. Code C92099.

Problems traced to the failure to maintain or establish techniques for controlling and verifying the product specifications (including materials used) identified by the manufacturer himself. 